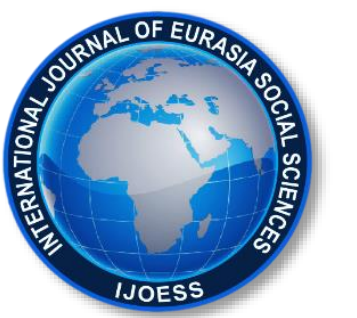

International Journal of Eurasia Social Sciences

Vol: 10, Issue: 37, pp. (709-725).

Research Article

Received: 08.03.2019 Accepted: 08.09.2019

\title{
AN EXAMINATION OF THE PROSPECTIVE SOCIAL STUDIES TEACHERS' LIFE SKILLS ${ }^{1}$
}

\author{
Ebru AY \\ Asst. Prof. Dr., Niğde Ömer Halisdemir University, ebru.ay@ohu.edu.tr \\ ORCID:0000-0002-3949-5202 \\ Salih USLU \\ Assoc. Prof. Dr., Niğde Ömer Halisdemir University, salihuslu@ohu.edu.tr \\ ORCID:0000-0003-0558-516X
}

\begin{abstract}
The aim of this study is to examine the prospective social studies teachers' life skills by a number of variables. The study group of the research consists of 299 prospective social studies teachers receiving education at the faculty of education of a state university. The research was designed on descriptive survey model. As data collection tool in the research, the "Life Skills Scale (LSS)" developed by Bolat and Balaman (2017) was used. The data were analyzed by using IBM SPSS 24.0 statistical package. As based on the results obtained from the research, it has been detected that the life skills of prospective social studies teachers are generally at high level. When the prospective social studies teachers' life skills are examined on the basis of sub-factors; it has been concluded that prospective teachers' empathy and self consciousness, decision-making and problem solving, creative and critical thinking, and communication and interpersonal relation skills are at high level. The prospective social studies teachers' life skills vary significantly at various sub-factors by gender, age, class level, a social institution, association and etc., which they are member of and where they engage in activities, the academic clubs which they join for relevant studies and their demand for receiving postgraduate education.
\end{abstract}

Keywords: Prospective Teacher, Social Studies, Life Skills

\footnotetext{
${ }^{1}$ This study was presented as an oral presentation in "7th International Symposium on Social Studies Education" on the 1113th October of 2018.
} 


\section{INTRODUCTION}

When we seek an answer to the question of "What skills are important?" in the $21^{\text {st }}$ century, we encounter with the skills pertaining to the $21^{\text {st }}$ century which can meet the changing needs of the individual and society that arise from the rapid changes in the field of science and technology. For this reason, there is a need for individuals who are able to produce information, use this information functionally in their lives, solve problem, think critically, have an entrepreneurial spirit, show decisiveness, have communication skills, develop empathy, approach matters inquisitively and use technology effectively (MEB, 2018a, p. 3).

Various definitions for the life skills included in the $21^{\text {st }}$ century's skills have been present in the fields of health, education and social policy (UNICEF, 2012, p. 7). The World Health Organization (WHO) and the United Nations International Children's Emergency Fund (UNICEF) define life skills as "abilities for adaptive and positive behaviour, that enable individuals to deal effectively with the demands and challenges of everyday life" (WHO, 1997, p. 1; UNICEF, 2003).

Life skills are the skills required so as to perform the tasks of a certain age and gender in the psychosocial, physical, professional, cognitive, moral and affective areas during the development of the individual (Powell, 1995: 24). Life skills are the competencies that help the individual out with adapting to the environment in which he leads his life and also skills needed to be possessed in order to put the information acquired by real life experiences into practice (Norman and Jordan, 2006: 1). At this point, life skills are the skills which can be learned, are needed to be used in every aspect of life and required for individuals to lead a healthy, functional and successful life by allowing their multi-dimensional development (Kılıç, 2015, p. 9). In this sense, the individual's using life skills in an effective manner contribute significantly to his self-improvement and social development.

The World Health Organization, by stating that life skills may differ from culture to culture, has classified the basic life skills which an individual must have as follows (WHO, 1997, p. 3):

- Decision-making and problem solving

- Creative and critical thinking

- Communication and interpersonal communication

- Self consciousness and empathy

- Emotion-focused coping and overcoming the stress

The United Nations International Children's Emergency Fund has gathered life skills into three categories as cognitive, personal and interpersonal (UNICEF, 2012, p. 9):

- Cognitive skills; critical thinking and problem solving skills for responsible decision making

- Personal skills; the skills necessary for self-management, drive and awareness 
- Interpersonal skills; the skills necessary for communication, negotiation, cooperation and team work, inclusion, empathy and advocacy (UNICEF, 2012, p.9).

According to the United Nations Educational, Scientific and Cultural Organization (UNESCO), life skills are the practice of knowledge, values, attitudes and skills that are significant in the process of personal development and lifelong learning. Life skills are also a result of the combination of manual skills and psychosocial competences (UNESCO, 2004, p. 5).

In summary, life skills are a group of psychosocial competencies and interpersonal skills that help people to make conscious decisions, to communicate effectively and to develop coping and self-management skills so that they can lead a healthy and productive life (Singh and Gera, 2015, p. 761).

Life skills have been included in some parts of the curricula in Turkey. They take place in Life Sciences and Sciences Curriculum as life skills (MEB, 2018b, MEB, 2018c). In Social Studies Curriculum, as it is also seen in Figure 1, although they are not mentioned as life skills, we see that some of the life skills are included in basic skills.

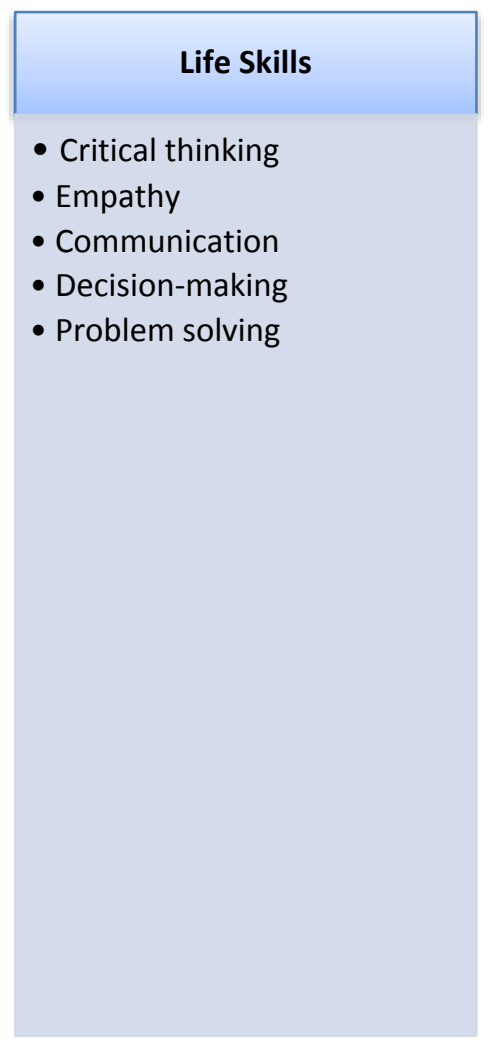

Skills
- Research
- Perceiving change and
continuity
- Entrepreneurship
- Observation
- Cooperation
- Detecting stereotype and
prejudice
- Using textual evidence
- Position analysis
- Perceiving space
- Self regulation
- Social participation
- Forming and explicating
table, graphic and diagram
- Using Turkish in an
accurate, pure and effective
manner
- Innovative thinking
- Perceiving time and
chronology

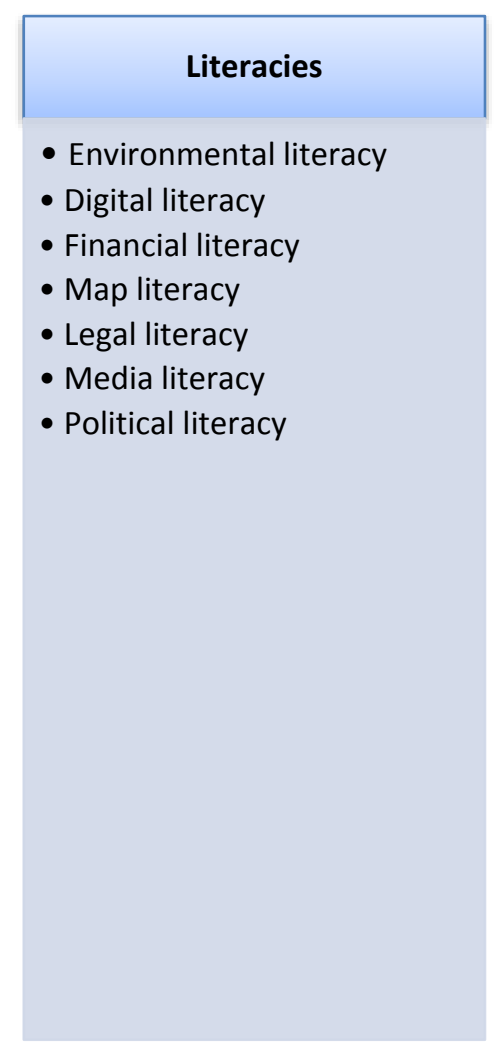

Figure 1: Basic Skills Included in Social Studies Curriculum

Resource: MEB, 2018a 
Social Studies Curriculum, by including these skills, aims to enable individuals to think and question rationally while making their decisions, make decision by thinking critically, think over social issues and search for a solution, be a problem solver and think in a creative manner as related to the situation and events considered important by the society and develop empathy (Kaya, 2008, p. 63). In this regard, social studies curriculum has a scope for enabling individuals to fit into the society in which they live and to gain the skills necessary for life.

It is important for teachers and prospective teachers to have the life skills, in terms of ensuring the students gain and improve the life skills in school environment. However, in literature, limited number of studies for determining the life skills of prospective teachers have been encountered (Kaur and Kaur Sandhu, 2016; Koyuncu, 2018; Kurtdede Fidan and Aydoğdu, 2018). Therefore, the aim of this study is to examine the prospective social studies teachers' life skills by a number of variables. The sub-problems created for the aim of the research are in the following:

1. What is the level of prospective social studies teachers' life skills?

2. Do the prospective social studies teachers' life skills differ significantly by the following variables?

2.1. Gender

2.2. Age

2.3. Class level

2.4. A social institution, association and etc., of which they are member

2.5. The academic clubs which they join for relevant studies, and

2.6. Their demand for receiving postgraduate education.

\section{METHOD}

\section{Research Model}

The survey model "is the research approach which aims to define a past or present situation as it is existed" (Karasar, 2010, p. 77). Survey researches aim to define the views and characteristics of the large masses (Büyüköztürk, Çakmak, Akgün, Karadeniz and Demirel, 2011, p. 231). For this reason, the survey model that is one of the descriptive research methods has been used in the research.

\section{Study Group}

The study group of the research consists of 299 prospective social studies teachers (PSST) who have participated in the research on a volunteer basis and receive education in the $1^{\text {st }}, 2^{\text {nd }}, 3^{\text {rd }}$ and $4^{\text {th }}$-year levels at the faculty of education of a state university at the fall term of the academic year 2018-2019. 


\section{Data Collection Tools}

As data collection tool in the research, personal information form prepared by the researchers and "Life Skills Scale (LSS)" developed by Bolat and Balaman (2017) were used.

\section{Personal Information Form}

In the personal information form, totally 6 questions which are related to the prospective teachers' gender, age, and class level, the social institution, association and etc., of which they are member, the academic clubs which they join for relevant studies and their demand for receiving postgraduate education are included.

\section{Life Skills Scale}

Life Skills Scale (LSS) developed by Bolat and Balaman (2017) is a 5-point Likert-type scale which consists of 5 sub-dimensions (coping with stress and emotions, empathy and self consciousness, decision-making and problem solving, creative and critical thinking, communication and interpersonal relations and 30 scale items (Bolat and Balaman, 2017).

\section{Validity and Reliability}

In the research carried out by Bolat and Balaman (2017), the Cronbach's Alpha internal consistency coefficient for the whole of Life Skills Scale is 0.90 . The reliability coefficient in itself of the items constituting the subfactor of coping with stress and emotions was calculated as 0.82 . The reliability coefficient in itself of the items constituting the sub-factor of empathy and self consciousness was calculated as 0.77 . The reliability coefficient in itself of the items constituting the sub-factor of decision-making and problem solving was calculated as 0.72 , the reliability coefficient in itself of the items constituting the sub-factor of creative and critical thinking as 0.73 and the reliability coefficient in itself of the items constituting the sub-factor of communication and interpersonal relations as 0.66 (Bolat and Balaman, 2017).

In this study, the Cronbach's Alpha internal consistency coefficient for the whole scale is 0.92. It was calculated as 0.77 in the sub-factor of coping with stress and emotions, 0.77 in the sub-factor of empathy and self consciousness, 0.80 in the sub-factor of decision-making and problem solving, 0.83 in the sub-factor of creative and critical thinking, and 0.75 in the sub-factor of communication and interpersonal relations.

\section{Analysis of Data}

In order to assess whether research data conforms to normal distribution, normal distribution analyses were carried out. Within the scope of this analysis, the mean score, minimum and maximum score width and skewness and kurtosis coefficients were calculated. Kolmogorov-Smirnov normality test was carried out. As the data conforms to normal distribution, in statistical analyses, t-test and one-way analysis of variance (ANOVA) included in parametric tests, and in order to determine between which groups the variances were, the LSD test 
were performed. Statistical processes were made by IBM SPSS 24.0 statistical package. In all analyses, significance level was accepted as $p \leq .05$.

By means of Independent Samples t-Test, it was determined whether the scores that the participants obtained from the life skills scale vary significantly by gender, the social institution, association and etc., which they are member of and involve in their activities, and the academic clubs which they join for relevant studies.

By using one-way analysis of variance (ANOVA) for independent samples, it was determined whether the scores that the participants obtained from the life skills scale vary as to be regarded statistically significant by age, class level and their demand for receiving postgraduate education. LSD multiple comparison test was performed so that the variances between groups could be determined.

\section{FINDINGS (RESULTS)}

\section{Findings for the Levels of Prospective Social Studies Teachers' Life Skills}

Table 1: Descriptive Statistical Results for The Levels of Prospective Social Studies Teachers' Life Skills

\begin{tabular}{cccc}
\hline Factor & $\mathbf{n}$ & $\bar{X}$ & Level \\
\hline Coping With Stress and Emotions & 299 & 3.29 & I Agree Moderately (Medium) \\
\hline Empathy and Self Consciousness & 299 & 3.87 & I Strongly Agree (High) \\
\hline Decision-Making and Problem Solving & 299 & 3.84 & I Strongly Agree (High) \\
\hline Creative and Critical Thinking & 299 & 3.96 & I Strongly Agree (High) \\
\hline Communication and Interpersonal Relations & 299 & 4.03 & I Strongly Agree (High) \\
\hline General Average & 299 & 3.76 & I Strongly Agree (High) \\
\hline
\end{tabular}

In the calculation of arithmetic mean scores for the answers given by prospective social studies teachers to the questions in life skills scale, the following ranges were taken as basis: I Disagree $(1.00<\bar{X} \leq 1.80)$, I Agree Slightly $(1.81<\bar{X} \leq 2.60)$, I Agree Moderately $(2.61<\bar{X} \leq 3.40)$, I Strongly Agree $(3.41<\bar{X} \leq 4.20)$, I Completely Agree $(4.21<\bar{X} \leq 5.00)$.

As based on Table 1, when the arithmetic mean scores for the levels of prospective social studies teachers' life skills are examined, it is seen that they have a medium-level skill in displaying their skills for coping with stress and emotions. It has been concluded that prospective social studies teachers' empathy and self consciousness, decision-making and problem solving, creative and critical thinking, and communication and interpersonal relation skills are at high level. Considering the data for the overall scale, it is seen that prospective teachers' life skills are at high level. In the light of the findings obtained, it can be said that the prospective social studies teachers need training in terms of coping with stress and emotions. 


\section{Findings for Gender Variable}

Table 2: Independent t-Test Results of Prospective Social Studies Teachers' Life Skills Scale Mean Scores by Gender Variable

\begin{tabular}{|c|c|c|c|c|c|c|c|}
\hline Factor & Gender & $n$ & $\bar{X}$ & Sd & df & $\mathbf{t}$ & $p$ \\
\hline \multirow{2}{*}{$\begin{array}{c}\text { Coping with Stress and } \\
\text { Emotions }\end{array}$} & Female & 204 & 23.01 & 4.88 & \multirow[b]{2}{*}{297} & \multirow[b]{2}{*}{.207} & \multirow[b]{2}{*}{.836} \\
\hline & Male & 95 & 23.15 & 5.73 & & & \\
\hline \multirow{2}{*}{$\begin{array}{c}\text { Empathy and Self } \\
\text { Consciousness }\end{array}$} & Female & 204 & 27.24 & 4.04 & \multirow{2}{*}{297} & \multirow{2}{*}{.929} & \multirow{2}{*}{.354} \\
\hline & Male & 95 & 26.73 & 5.23 & & & \\
\hline \multirow{2}{*}{$\begin{array}{c}\text { Decision-Making and } \\
\text { Problem Solving }\end{array}$} & Female & 204 & 27.19 & 4.41 & \multirow{2}{*}{297} & \multirow{2}{*}{1.712} & \multirow{2}{*}{.088} \\
\hline & Male & 95 & 26.21 & 5.02 & & & \\
\hline \multirow{2}{*}{$\begin{array}{c}\text { Creative and Critical } \\
\text { Thinking } \\
\end{array}$} & Female & 204 & 20.04 & 3.47 & \multirow{2}{*}{297} & \multirow{2}{*}{1.594} & \multirow{2}{*}{.112} \\
\hline & Male & 95 & 19.33 & 3.87 & & & \\
\hline \multirow{2}{*}{$\begin{array}{c}\text { Communication and } \\
\text { Interpersonal Relations }\end{array}$} & Female & 204 & 16.59 & 2.65 & \multirow{2}{*}{297} & \multirow{2}{*}{4.324} & \multirow{2}{*}{$.000^{*}$} \\
\hline & Male & 95 & 15.04 & 3.33 & & & \\
\hline \multirow{2}{*}{ Total } & Female & 204 & 114.07 & 15.44 & \multirow{2}{*}{297} & \multirow{2}{*}{1.737} & \multirow{2}{*}{.083} \\
\hline & Male & 95 & 110.45 & 19.38 & & & \\
\hline
\end{tabular}

$* p<.05$

When Table 2 is examined, between the PSSTs' gender and life skills sub-factor levels, it has been seen that no significant difference is available in the factors of skills of coping with stress and emotions $\left(t_{(297)}=.207 ; p>.05\right)$, empathy and self consciousness skills $\left(\mathrm{t}_{(297)}=.929 ; \mathrm{p}>.05\right)$, decision-making and problem solving skills $\left(\mathrm{t}_{(297)}=.088\right.$; $\mathrm{p}>.05)$, creative and critical thinking skills $\left(\mathrm{t}_{(297)}=.112 ; \mathrm{p}>.05\right)$ and in terms of the total score in scale-wide $\left(t_{(297)}=.083 ; p>.05\right)$. However, a statistically significant difference has been found in the scale dimension for communication and interpersonal relations factor $\left(\mathrm{t}_{(297)}=4.324 ; \mathrm{p}<.05\right)$. According to the obtained findings, it has been inferred as a conclusion that female prospective social studies teachers' communication and interpersonal relation skills are higher, compared to the male prospective teachers.

\section{Findings for Age Variable}

Table 3. One-Way ANOVA Results of the Scale Mean Scores for Prospective Social Studies Teachers' Life Skills Levels by Age Variable

\begin{tabular}{|c|c|c|c|c|c|c|c|c|c|c|c|}
\hline tò & Age & $n$ & $\bar{X}$ & Sd & SV & SS & df & MS & $\mathbf{F}$ & $\mathbf{p}$ & $\begin{array}{l}\text { Source of } \\
\text { Difference } \\
\text { (LSD) }\end{array}$ \\
\hline \multirow{8}{*}{ 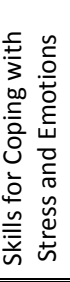 } & 1) 18 & 33 & 21.03 & 5.72 & Between- & 400.680 & 5 & 80.136 & \multirow{8}{*}{3.123} & \multirow{5}{*}{$.009 *$} & $2-1$ \\
\hline & & & & & Groups & & & & & & $4-1$ \\
\hline & 2) 19 & 55 & 23.47 & 5.51 & Within- & 7519.353 & 293 & 25.663 & & & $5-1$ \\
\hline & & & & & Group & & & & & & $6-1$ \\
\hline & 3) 20 & 71 & 22.10 & 4.24 & Total & 7920.033 & 298 & & & & $6-3$ \\
\hline & 4) 21 & 76 & 23.29 & 5.16 & & & & & & & \\
\hline & 5) 22 & 31 & 23.65 & 5.70 & & & & & & & \\
\hline & 6) $22+$ & 33 & 25.36 & 4.33 & & & & & & & \\
\hline \multirow{6}{*}{ 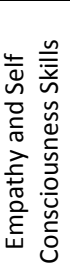 } & 1) 18 & 33 & 25.73 & 4.39 & $\begin{array}{c}\text { Between- } \\
\text { Groups }\end{array}$ & 205.803 & 5 & 41.161 & \multirow{6}{*}{2.115} & \multirow{6}{*}{.064} & \\
\hline & 2) 19 & 55 & 27.47 & 3.59 & $\begin{array}{l}\text { Within- } \\
\text { Group }\end{array}$ & 5701.428 & 293 & 19.459 & & & \\
\hline & 3) 20 & 71 & 26.75 & 4.49 & Total & 5907.231 & 298 & & & & \\
\hline & 4) 21 & 76 & 26.64 & 5.20 & & & & & & & \\
\hline & 5) 22 & 31 & 27.77 & 3.83 & & & & & & & \\
\hline & 6) $22+$ & 33 & 28.82 & 3.97 & & & & & & & \\
\hline
\end{tabular}




\begin{tabular}{|c|c|c|c|c|c|c|c|c|c|c|c|}
\hline \multirow{6}{*}{ 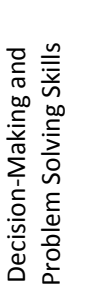 } & 1) 18 & 33 & 26.48 & 4.13 & $\begin{array}{c}\text { Between- } \\
\text { Groups }\end{array}$ & 226.911 & 5 & 45.382 & \multirow{3}{*}{2.162} & \multirow{3}{*}{.058} & \\
\hline & 2) 19 & 55 & 27.36 & 4.77 & $\begin{array}{l}\text { Within- } \\
\text { Group }\end{array}$ & 6150.755 & 293 & 20.992 & & & \\
\hline & 3) 20 & 71 & 26.23 & 4.88 & Total & 6377.666 & 298 & & & & \\
\hline & 4) 21 & 76 & 26.28 & 4.83 & & & & & & & \\
\hline & 5) 22 & 31 & 27.16 & 4.72 & & & & & & & \\
\hline & 6) $22+$ & 33 & 29.00 & 3.02 & & & & & & & \\
\hline \multirow{6}{*}{ 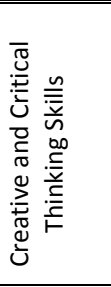 } & 1) 18 & 33 & 19.82 & 3.91 & $\begin{array}{c}\text { Between- } \\
\text { Groups }\end{array}$ & 59.999 & 5 & 12.000 & \multirow{6}{*}{.919} & \multirow{3}{*}{.469} & \\
\hline & 2) 19 & 55 & 20.13 & 3.90 & $\begin{array}{l}\text { Within- } \\
\text { Group }\end{array}$ & 3825.513 & 293 & 13.056 & & & \\
\hline & 3) 20 & 71 & 19.58 & 3.34 & Total & 3885.512 & 298 & & & & \\
\hline & 4) 21 & 76 & 19.54 & 3.75 & & & & & & & \\
\hline & 5) 22 & 31 & 19.32 & 3.82 & & & & & & & \\
\hline & 6) $22+$ & 33 & 20.88 & 2.77 & & & & & & & \\
\hline \multirow{6}{*}{ 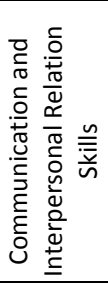 } & 1) 18 & 33 & 15.85 & 2.81 & $\begin{array}{c}\text { Between- } \\
\text { Groups }\end{array}$ & 117.263 & 5 & 23.453 & \multirow{3}{*}{2.745} & \multirow{3}{*}{$.019 *$} & 2-1 \\
\hline & 2) 19 & 55 & 17.16 & 2.91 & $\begin{array}{l}\text { Within- } \\
\text { Group }\end{array}$ & 2502.924 & 293 & 8.542 & & & $2-3$ \\
\hline & 3) 20 & 71 & 15.75 & 2.91 & Total & 2620.187 & 298 & & & & \\
\hline & 4-) 21 & 76 & 15.47 & 3.29 & & & & & & & \\
\hline & 5) 22 & 31 & 16.10 & 2.82 & & & & & & & \\
\hline & 6) $22+$ & 33 & 16.76 & 2.18 & & & & & & & \\
\hline \multirow{9}{*}{$\begin{array}{l}\bar{\pi} \\
\stackrel{0}{0} \\
\qquad\end{array}$} & 1) 18 & 33 & 108.91 & 16.21 & Between- & 3692.239 & 5 & 738.44 & \multirow{9}{*}{2.677} & \multirow{5}{*}{$.022^{*}$} & \\
\hline & & & & & Groups & & & 8 & & & $6-1$ \\
\hline & 2) 19 & 55 & 115.60 & 15.86 & Within- & 80826.991 & 293 & 275.86 & & & $6-3$ \\
\hline & & & & & Group & & & 0 & & & $6-4$ \\
\hline & 3) 20 & 71 & 110.39 & 16.04 & Total & 84519.231 & 298 & & & & \\
\hline & 4) 21 & 76 & 111.22 & 18.44 & & & & & & & \\
\hline & 5) 22 & 31 & 114.00 & 18.44 & & & & & & & \\
\hline & 6) $22+$ & 33 & 120.82 & 12.63 & & & & & & & \\
\hline & Total & 299 & 112.92 & 16.84 & & & & & & & \\
\hline
\end{tabular}

$* \mathrm{p}<.05$

When Table 3 is examined, between the PSSTs' age and life skills levels, it has been seen that no significant difference is available in the factors of empathy and self consciousness skills $\left(F_{(5-293)}=2.115 ; p>05\right)$, decisionmaking and problem solving skills $\left(\mathrm{F}_{(5-293)}=2.162 ; \mathrm{p}>.05\right)$ and creative and critical thinking skills $\left(\mathrm{F}_{(5-293)}=.919\right.$; $p>$.05). A statistically significant difference by age variable has been found in the factors of skills for coping with stress and emotions $\left(\mathrm{F}_{(5-293)}=3.123 ; \mathrm{p}<.05\right)$, communication and interpersonal relation skills $\left(\mathrm{F}_{(5-293)}=2.745\right.$; $p<.05)$ and in terms of the total score in scale-wide $\left(F_{(5-293)}=2.677 ; p<.05\right)$. In the light of the findings obtained, it has been concluded that the skill levels of coping with stress and emotions are higher for the prospective teachers who are 19, 21 and 22 and over 22, compared to the ones who are at the age of 18 . In the dimension of communication and interpersonal relation skills, it has been realized that the skill levels of prospective teachers at the age of 19 for communication and interpersonal relations are higher than the prospective teachers who are at the age level of 18, 20 and 21. In the scale-wide, as a result, it has been found that the life skill levels of prospective teachers over 22 are higher than the ones who are at the age level of 18,20 and 21. 


\section{Findings for Class Level Variable}

Table 4. One-Way ANOVA Results of the Scale Mean Scores for Prospective Social Studies Teachers' Life Skills Levels by Class Level Variable

\begin{tabular}{|c|c|c|c|c|c|c|c|c|c|c|c|}
\hline 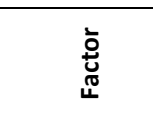 & Class & $\mathbf{n}$ & $\bar{X}$ & Sd & SV & SS & df & MS & $\mathbf{F}$ & $\mathbf{p}$ & $\begin{array}{l}\text { Source of } \\
\text { Difference } \\
\text { (LSD) }\end{array}$ \\
\hline \multirow{4}{*}{ 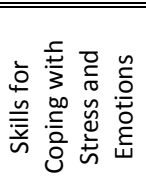 } & 1 & 76 & 22.43 & 5.44 & $\begin{array}{l}\text { Between- } \\
\text { Groups }\end{array}$ & 206.115 & 3 & 68.705 & \multirow{3}{*}{2.627} & \multirow{3}{*}{.051} & \\
\hline & 2 & 64 & 22.55 & 4.64 & Within-Group & 7713.919 & 295 & 26.149 & & & \\
\hline & 3 & 87 & 22.77 & 5.31 & Total & 7920.033 & 298 & & & & \\
\hline & 4 & 72 & 24.51 & 4.91 & & & & & & & \\
\hline \multirow{4}{*}{ 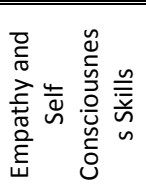 } & 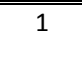 & 76 & 26.67 & 3.92 & $\begin{array}{l}\text { Between- } \\
\text { Groups }\end{array}$ & 125.342 & 3 & 41.781 & \multirow{3}{*}{2.132} & \multirow{3}{*}{.096} & \\
\hline & 2 & 64 & 26.27 & 4.38 & Within-Group & 5781.889 & 295 & 19.600 & & & \\
\hline & 3 & 87 & 27.22 & 4.65 & Total & 5907.231 & 298 & & & & \\
\hline & 4 & 72 & 28.06 & 4.68 & & & & & & & \\
\hline \multirow{4}{*}{ 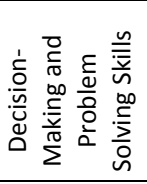 } & 1 & 76 & 26.70 & 4.70 & $\begin{array}{c}\text { Between- } \\
\text { Groups }\end{array}$ & 198.514 & 3 & 66.171 & \multirow{4}{*}{3.159} & \multirow{3}{*}{$.025^{*}$} & \multirow{3}{*}{$4-2$} \\
\hline & 2 & 64 & 25.66 & 4.86 & Within-Group & 6179.151 & 295 & 20.946 & & & \\
\hline & 3 & 87 & 26.97 & 4.61 & Total & 6377.666 & 298 & & & & \\
\hline & 4 & 72 & 28.06 & 4.13 & & & & & & & \\
\hline \multirow{4}{*}{ 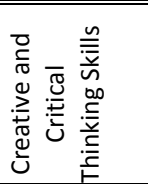 } & 1 & 76 & 19.83 & 4.13 & $\begin{array}{c}\text { Between- } \\
\text { Groups } \\
\end{array}$ & 34.733 & 3 & 11.578 & \multirow{3}{*}{.887} & \multirow{3}{*}{.448} & \\
\hline & 2 & 64 & 19.41 & 3.88 & Within-Group & 3850.779 & 295 & 13.053 & & & \\
\hline & 3 & 87 & 19.64 & 3.28 & Total & 3885.512 & 298 & & & & \\
\hline & 4 & 72 & 20.36 & 3.14 & & & & & & & \\
\hline \multirow{4}{*}{ 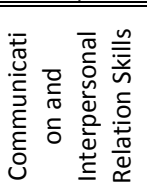 } & 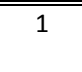 & 76 & 16.54 & 3.19 & $\begin{array}{c}\text { Between- } \\
\text { Groups }\end{array}$ & 26.336 & 3 & 8.779 & \multirow{3}{*}{.998} & \multirow{3}{*}{.394} & \\
\hline & 2 & 64 & 15.72 & 2.89 & Within-Group & 2593.851 & 295 & 8.793 & & & \\
\hline & 3 & 87 & 15.94 & 2.99 & Total & 2620.187 & 298 & & & & \\
\hline & 4 & 72 & 16.15 & 2.74 & & & & & & & \\
\hline \multirow{5}{*}{ 劳 } & 1 & 76 & 112.17 & 16.49 & $\begin{array}{c}\text { Between- } \\
\text { Groups }\end{array}$ & 2044.797 & 3 & 681.599 & \multirow{5}{*}{2.438} & \multirow{5}{*}{.065} & \\
\hline & 2 & 64 & 109.59 & 16.71 & Within-Group & 82474.434 & 295 & 279.574 & & & \\
\hline & 3 & 87 & 112.54 & 17.70 & Total & 84519.231 & 298 & & & & \\
\hline & 4 & 72 & 117.14 & 15.73 & & & & & & & \\
\hline & Total & 299 & 112.92 & 16.84 & & & & & & & \\
\hline
\end{tabular}

$* p<.05$

When Table 4 is examined, between the PSSTs' class and life skills levels, it has been seen that no significant difference is available in the factors of skills for coping with stress and emotions $\left(\mathrm{F}_{(3-295)}=2.627 ; \mathrm{p}>.05\right)$, empathy and self consciousness skills $\left(\mathrm{F}_{(3-295)}=2.132 ; \mathrm{p}>.05\right)$, creative and critical thinking skills $\left(\mathrm{F}_{(3-295)}=.887 ; \mathrm{p}>.05\right)$, communication and interpersonal relation skills $\left(\mathrm{F}_{(3-295)}=.998 ; \mathrm{p}>.05\right)$ and in terms of the total score in scalewide $\left(F_{(3-295)}=2.677 ; p>.05\right)$. A significant relation as to the class level variable has been detected in the dimension of decision-making and problem solving skills factor $\left(F_{(3-295)}=3.159 ; p<.05\right)$. According to the obtained findings, it has been realized that the $4^{\text {th }}$-year prospective social studies teachers have a higher level of decision-making and problem solving skills than the prospective teachers receiving education at the $2^{\text {nd }}$-year level. 


\section{Findings for the Variable of Social Institution, Association and etc., which the PSSTs are Member of and} Involve in their Activities

Table 5. Independent t-Test Results of Prospective Social Studies Teachers' Life Skills Scale Mean Scores by the Variable of Social Institution, Association and etc., which the PSSTs are Member of and Involve in their Activities

\begin{tabular}{|c|c|c|c|c|c|c|c|}
\hline Factor & $\begin{array}{l}\text { Institution } \\
\text { Association }\end{array}$ & $\mathbf{n}$ & $\bar{X}$ & Sd & df & $\mathbf{t}$ & $\mathbf{p}$ \\
\hline \multirow{2}{*}{$\begin{array}{c}\text { Coping with Stress and } \\
\text { Emotions }\end{array}$} & Available & 47 & 23.98 & 5.38 & \multirow{2}{*}{297} & \multirow{2}{*}{1.337} & \multirow{2}{*}{.182} \\
\hline & None-Available & 252 & 22.88 & 5.11 & & & \\
\hline \multirow{2}{*}{$\begin{array}{c}\text { Empathy and Self } \\
\text { Consciousness } \\
\end{array}$} & Available & 47 & 28.26 & 4.41 & \multirow{2}{*}{297} & \multirow{2}{*}{1.986} & \multirow{2}{*}{$.048^{*}$} \\
\hline & None-Available & 252 & 26.86 & 4.43 & & & \\
\hline \multirow{2}{*}{$\begin{array}{c}\text { Decision-Making and } \\
\text { Problem Solving }\end{array}$} & Available & 47 & 28.02 & 5.42 & \multirow{2}{*}{297} & \multirow{2}{*}{1.850} & \multirow{2}{*}{.065} \\
\hline & None-Available & 252 & 26.67 & 4.44 & & & \\
\hline \multirow{2}{*}{$\begin{array}{c}\text { Creative and Critical } \\
\text { Thinking }\end{array}$} & Available & 47 & 20.47 & 4.11 & \multirow{2}{*}{297} & \multirow{2}{*}{1.357} & \multirow{2}{*}{.176} \\
\hline & None-Available & 252 & 19.69 & 3.51 & & & \\
\hline \multirow{2}{*}{$\begin{array}{c}\text { Communication and } \\
\text { Interpersonal Relations }\end{array}$} & Available & 47 & 15.94 & 3.44 & \multirow{2}{*}{297} & \multirow{2}{*}{.404} & \multirow{2}{*}{.686} \\
\hline & None-Available & 252 & 16.13 & 2.87 & & & \\
\hline \multirow{2}{*}{ Total } & Available & 47 & 116.66 & 19.08 & \multirow{2}{*}{297} & \multirow{2}{*}{1.662} & \multirow{2}{*}{.098} \\
\hline & None-Available & 252 & 112.23 & 16.34 & & & \\
\hline
\end{tabular}

${ }^{*} \mathrm{p}<.05$

When Table 5 is examined, between the variable of a social institution, association and etc., which the PSSTs are member of and involve in their activities and the life skills sub-factor levels, it has been seen that no significant difference is available in the factors of skills for coping with stress and emotions $\left(\mathrm{t}_{(297)}=1.337 ; \mathrm{p}>.05\right)$, decision-making and problem solving skills $\left(\mathrm{t}_{(297)}=1.850 ; \mathrm{p}>.05\right)$, creative and critical thinking skills $\left(\mathrm{t}_{(297)}=1.357\right.$; $\mathrm{p}>.05)$, communication and interpersonal relation skills $\left(\mathrm{t}_{(297)}=.404 ; \mathrm{p}>.05\right)$ and in terms of the total score in scale-wide $\left(t_{(297)}=1.662 ; p>.05\right)$. A significant difference is encountered in the dimension of empathy and self consciousness skills factor $\left(\mathrm{t}_{(297)}=1.986 ; \mathrm{p}<.05\right)$. According to the obtained findings, it has been seen that a result in favor of prospective social studies teachers being a member and involving in the activities of a social institution, association, and etc., is present for the levels of empathy and self consciousness skills.

\section{Findings for the Academic Clubs which PSSTs Join for Relevant Studies}

Table 6. Independent t-Test Results of Prospective Social Studies Teachers' Life Skills Scale Mean Scores by the Variable of Academic Clubs which the PSSTs Join for Relevant Studies

\begin{tabular}{|c|c|c|c|c|c|c|c|}
\hline Factor & Academic Club & $\mathrm{n}$ & $\bar{X}$ & Sd & df & $\mathbf{t}$ & $\mathbf{p}$ \\
\hline \multirow[b]{2}{*}{$\begin{array}{l}\text { Coping with Stress and } \\
\text { Emotions }\end{array}$} & Available & 31 & 24.26 & 6.32 & \multirow[b]{2}{*}{297} & \multirow[b]{2}{*}{1.372} & \multirow[b]{2}{*}{.171} \\
\hline & $\begin{array}{c}\text { None- } \\
\text { Available }\end{array}$ & 268 & 22.92 & 5.00 & & & \\
\hline \multirow{2}{*}{$\begin{array}{l}\text { Empathy and Self } \\
\text { Consciousness }\end{array}$} & Available & 31 & 28.42 & 5.95 & \multirow[b]{2}{*}{297} & \multirow[b]{2}{*}{1.780} & \multirow[b]{2}{*}{.076} \\
\hline & $\begin{array}{c}\text { None- } \\
\text { Available }\end{array}$ & 268 & 26.92 & 4.23 & & & \\
\hline \multirow[b]{2}{*}{$\begin{array}{l}\text { Decision-Making and } \\
\text { Problem Solving }\end{array}$} & Available & 31 & 29.10 & 5.15 & \multirow[b]{2}{*}{297} & \multirow[b]{2}{*}{2.852} & \multirow[b]{2}{*}{$.005^{*}$} \\
\hline & $\begin{array}{c}\text { None- } \\
\text { Available } \\
\end{array}$ & 268 & 26.62 & 4.50 & & & \\
\hline \multirow{2}{*}{$\begin{array}{c}\text { Creative and Critical } \\
\text { Thinking }\end{array}$} & Available & 31 & 21.06 & 3.92 & \multirow[b]{2}{*}{297} & \multirow[b]{2}{*}{2.050} & \multirow[b]{2}{*}{$.041^{*}$} \\
\hline & $\begin{array}{c}\text { None- } \\
\text { Available }\end{array}$ & 268 & 19.67 & 3.55 & & & \\
\hline Communication and & Available & 31 & 16.23 & 3.91 & 297 & .255 & .799 \\
\hline
\end{tabular}




\begin{tabular}{|c|c|c|c|c|c|c|c|}
\hline Interpersonal Relations & $\begin{array}{c}\text { None- } \\
\text { Available }\end{array}$ & 268 & 16.08 & 2.84 & & & \\
\hline Total & Available & 31 & 119.06 & 21.01 & 297 & 2.158 & $.032 *$ \\
\hline
\end{tabular}

$* p<.05$

When Table 6 is examined, between the variable of the academic club(s) which the PSSTs join for relevant studies and the life skills sub-factor levels, no significant difference has been found in the factors of skills for coping with stress and emotions $\left(\mathrm{t}_{(297)}=1.372 ; \mathrm{p}>.05\right)$, empathy and self consciousness skills $\left(\mathrm{t}_{(297)}=1.780\right.$; $\mathrm{p}>.05)$, and communication and interpersonal relation skills $\left(\mathrm{t}_{(297)}=.255 ; \mathrm{p}>.05\right)$; however, it has been concluded that there is a significant difference in the factors of decision-making and problem solving skills $\left(\mathrm{t}_{(297)}=2.852\right.$; $\mathrm{p}<.05)$, creative and critical thinking skills $\left(\mathrm{t}_{(297)}=2.050 ; \mathrm{p}<.05\right)$ and in terms of the total score in scale-wide $\left(t_{(297)}=2.158 ; p<.05\right)$. According to the obtained findings, it has been found that the prospective social studies teachers' decision-making and problem solving skills, creative and critical thinking skills are higher in the ones who take part in the relevant studies of an academic club than the others who don't join such academic clubs at university. Considering the findings for overall scale, also the life skills levels have been resulted in favor of prospective social studies teachers taking part in the relevant studies of an academic club at university.

\section{Findings for the Demand for Receiving Postgraduate Education}

Table 7. One-Way ANOVA Results of the Scale Mean Scores for Prospective Social Studies Teachers' Life Skills Levels by the Variable of PSSTs' Demand for Receiving Postgraduate Education

\begin{tabular}{|c|c|c|c|c|c|c|c|c|c|c|c|}
\hline 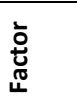 & $\begin{array}{c}\text { Postgraduate } \\
\text { Education }\end{array}$ & $n$ & $\bar{X}$ & Sd & SV & SS & df & MS & $\mathbf{F}$ & $p$ & $\begin{array}{l}\text { Source of } \\
\text { Difference } \\
\text { (LSD) }\end{array}$ \\
\hline \multirow{4}{*}{ 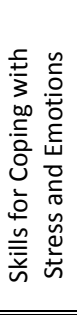 } & 1) No & 178 & 22.67 & 5.28 & $\begin{array}{l}\text { Between- } \\
\text { Groups }\end{array}$ & 109.784 & 3 & 36.595 & \multirow{4}{*}{1.382} & \multirow{4}{*}{.248} & \\
\hline & 2) Yes & 22 & 22.41 & 6.12 & $\begin{array}{l}\text { Within- } \\
\text { Group }\end{array}$ & 7810.250 & 295 & 26.475 & & & \\
\hline & $\begin{array}{c}\text { 3) (Yes) } \\
\text { Improving } \\
\text { Oneself }\end{array}$ & 81 & 23.99 & 4.73 & Total & 7920.033 & 298 & & & & \\
\hline & $\begin{array}{c}\text { 4) (Yes) } \\
\text { Ideal Target } \\
\end{array}$ & 18 & 23.50 & 4.16 & & & & & & & \\
\hline \multirow{4}{*}{ 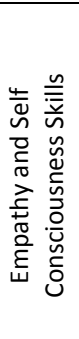 } & 1) No & 178 & 26.37 & 4.53 & $\begin{array}{l}\text { Between- } \\
\text { Groups }\end{array}$ & 223.888 & 3 & 74.629 & \multirow{4}{*}{3.874} & \multirow{4}{*}{$.010^{*}$} & \multirow{4}{*}{ 3-1 } \\
\hline & 2) Yes & 22 & 27.77 & 5.12 & $\begin{array}{l}\text { Within- } \\
\text { Group }\end{array}$ & 5683.342 & 295 & 19.266 & & & \\
\hline & $\begin{array}{c}\text { 3) (Yes) } \\
\text { Improving } \\
\text { Oneself } \\
\end{array}$ & 81 & 28.14 & 4.05 & Total & 5907.231 & 298 & & & & \\
\hline & $\begin{array}{c}\text { 4) (Yes) } \\
\text { Ideal Target }\end{array}$ & 18 & 28.44 & 3.33 & & & & & & & \\
\hline \multirow{4}{*}{ 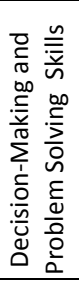 } & 1) No & 178 & 25.87 & 4.71 & $\begin{array}{c}\text { Between- } \\
\text { Groups }\end{array}$ & 460.823 & 3 & 153.608 & \multirow{4}{*}{7.659} & \multirow{4}{*}{$.000 *$} & \multirow{4}{*}{$\begin{array}{l}2-1 \\
3-1 \\
4-1\end{array}$} \\
\hline & 2) Yes & 22 & 27.86 & 4.40 & $\begin{array}{l}\text { Within- } \\
\text { Group }\end{array}$ & 5916.843 & 295 & 20.057 & & & \\
\hline & $\begin{array}{l}\text { 3) (Yes) } \\
\text { Improving } \\
\text { Oneself } \\
\end{array}$ & 81 & 28.43 & 3.97 & Total & 6377.666 & 298 & & & & \\
\hline & 4) (Yes) & 18 & 28.72 & 4.31 & & & & & & & \\
\hline
\end{tabular}




\begin{tabular}{|c|c|c|c|c|c|c|c|c|c|c|c|}
\hline & Ideal Target & & & & & & & & & & \\
\hline \multirow{5}{*}{ 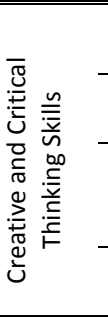 } & 1) No & 178 & 19.33 & 3.88 & $\begin{array}{l}\text { Between- } \\
\text { Groups }\end{array}$ & 122.250 & 3 & 40.750 & \multirow{5}{*}{3.194} & \multirow{5}{*}{$.024 *$} & \multirow{5}{*}{$\begin{array}{l}3-1 \\
4-1\end{array}$} \\
\hline & 2) Yes & 22 & 20.41 & 3.03 & $\begin{array}{l}\text { Within- } \\
\text { Group }\end{array}$ & 3763.262 & 295 & 12.757 & & & \\
\hline & 3) (Yes) & & & & & 3885.512 & 298 & & & & \\
\hline & $\begin{array}{l}\text { Improving } \\
\text { Oneself }\end{array}$ & 81 & 20.33 & 3.19 & Total & & & & & & \\
\hline & $\begin{array}{c}\text { 4) (Yes) } \\
\text { Ideal Target }\end{array}$ & 18 & 21.50 & 2.38 & & & & & & & \\
\hline \multirow{5}{*}{ 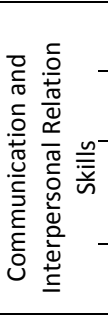 } & 1) No & 178 & 15.69 & 3.19 & $\begin{array}{c}\text { Between- } \\
\text { Groups }\end{array}$ & 84.918 & 3 & 28.306 & \multirow{5}{*}{3.294} & \multirow{5}{*}{$.021 *$} & \multirow{5}{*}{$\begin{array}{l}2-1 \\
3-1 \\
4-1\end{array}$} \\
\hline & 2) Yes & 22 & 17.14 & 2.44 & $\begin{array}{l}\text { Within- } \\
\text { Group }\end{array}$ & 2535.269 & 295 & 8.594 & & & \\
\hline & 3) (Yes) & & & & & 2620.187 & 298 & & & & \\
\hline & $\begin{array}{c}\text { Improving } \\
\text { Oneself }\end{array}$ & 81 & 16.47 & 2.59 & Total & & & & & & \\
\hline & $\begin{array}{c}\text { 4) (Yes) } \\
\text { Ideal Target }\end{array}$ & 18 & 17.17 & 2.04 & & & & & & & \\
\hline \multirow{6}{*}{ 焉 } & 1) No & 178 & 109.93 & 17.52 & $\begin{array}{c}\text { Between- } \\
\text { Groups }\end{array}$ & 40808.245 & 3 & 1362.415 & \multirow{6}{*}{4.997} & \multirow{6}{*}{$.002 *$} & \multirow{6}{*}{$\begin{array}{l}3-1 \\
4-1\end{array}$} \\
\hline & 2) Yes & 22 & 115.59 & 17.64 & $\begin{array}{l}\text { Within- } \\
\text { Group }\end{array}$ & 80431.986 & 295 & 272.651 & & & \\
\hline & 3) (Yes) & & & & & 84519.231 & 298 & & & & \\
\hline & $\begin{array}{l}\text { Improving } \\
\text { Oneself }\end{array}$ & 81 & 117.36 & 14.87 & Total & & & & & & \\
\hline & $\begin{array}{c}\text { 4) (Yes) } \\
\text { Ideal Target }\end{array}$ & 18 & 119.33 & 10.56 & & & & & & & \\
\hline & Total & 299 & 112.92 & 16.84 & & & & & & & \\
\hline
\end{tabular}

$* p<.05$

When Table 7 is examined, between the variable of the PSSTs' demand for receiving postgraduate education and the life skills levels, no significant difference has been found in the factor of skills for coping with stress and emotions $\left(F_{(3-295)}=1.382 ; p>.05\right)$; on the other hand, a significant difference has been seen in the factors of empathy and self consciousness skills $\left(\mathrm{F}_{(3-295)}=3.874 ; \mathrm{p}<.05\right)$, decision-making and problem solving skills $\left(\mathrm{F}_{(3-295)}=\right.$ 7.659; $\mathrm{p}<.05)$, creative and critical thinking skills $\left(\mathrm{F}_{(3-295)}=3.194 ; \mathrm{p}<.05\right)$, communication and interpersonal relation skills $\left(F_{(3-295)}=3.294 ; p<.05\right)$ and in terms of the total score in scale-wide $\left(F_{(3-295)}=4.997 ; p<.05\right)$. In the light of the findings obtained, it has been concluded that the empathy and self consciousness skill levels of prospective teachers who consider postgraduate education as improving oneself are higher than the others who do not want to receive postgraduate education. The creative and critical thinking skill levels of prospective teachers who consider postgraduate education as improving oneself and ideal target have been found higher than the ones who do not want to receive postgraduate education. Furthermore, it has been realized that the decision-making and problem solving skill and communication and interpersonal relation skill levels of prospective teachers who have a desire for receiving postgraduate education by regarding it as improving oneself and also ideal target are higher, compared to the prospective teachers who do not want to receive postgraduate education. When the findings for the scale general total are analyzed, it can be stated that the life skill levels of prospective teachers adopting postgraduate education as a way of improving oneself and an ideal target are higher than those of prospective teachers who do not want to receive postgraduate education. 


\section{CONCLUSION and DISCUSSION}

Life skills are the skills acquired in the course of life. The acquisition and practice of life skills in an effective manner have an influence on how we perceive ourselves and other people. Life skills play a crucial role in the development of mentally well-being by contributing to our self-efficacy, self-confidence and self-respect (WHO, 1997).

In this study which aims to examine the prospective social studies teachers' life skills by a certain number of variables, it is seen that prospective teachers' life skills are generally at a high level. When the prospective social studies teachers' life skills are examined on the basis of sub-factors; it has been concluded that prospective teachers' empathy and self consciousness, decision-making and problem solving, creative and critical thinking, and communication and interpersonal relation skills are at high level. This result indicates that having life skills and managing to actualize these skills in life will make a positive contribution to both the one's inner world and relations with the external environment (Ümmet and Demirci, 2017). It has been detected that prospective teachers' skills for coping with stress and emotions are at moderate level. According to this result obtained, it can be said that prospective social studies teachers need training for coping with stress and emotions. It is required to learn how to be relaxed in order to prevent intense emotions and tensions caused by stress from resulting in health problems (WHO, 1997). Also, in the research carried out by Kaur and Kaur Sandhu (2016), as based on the total score of the life skills scale applied to the prospective teachers, dimensions of self-awareness and coping with stress are below the average.

Between the PSSTs' gender and life skills sub-factor levels, it has been seen that no significant difference is available in the factors of skills of coping with stress and emotions, empathy and self consciousness skills, decision-making and problem solving skills, and creative and critical thinking skills and in terms of the total score in scale-wide. However, a statistically significant difference has been detected in the dimension for communication and interpersonal relations factor. In the light of the obtained findings, it has been concluded that female prospective social studies teachers' communication and interpersonal relation skills are higher, compared to the male prospective teachers. Similarly, in the research carried out by Kaur and Kaur Sandhu (2016), it has been determined that the skills of interpersonal communication, making decision and coping with stress, which are the sub-dimensions of prospective teachers' life skills scale, are higher in females than males. Yet, in the research by Koyuncu (2018), it has been found that there is not a statistically significant difference between the genders of prospective teachers receiving pedagogical formation education and the whole of life skills scale and its sub-dimensions.

It has been detected that no significant difference is available in the factors of empathy and self consciousness skills, decision-making and problem solving skills and creative and critical thinking skills, between the prospective social studies teachers' age levels and the level of life skills. However, a statistically significant difference by age variable has been found in skills for coping with stress and emotions, communication and interpersonal relation skills and in terms of the total score in scale-wide. According to the results obtained, it 
has been concluded that the skill levels of coping with stress and emotions are higher for the prospective teachers who are 19, 21 and 22 and over 22, compared to the ones who are at the age of 18 . Because a central feature of human development is to cope with stress (Compas, 1987). In the dimension of communication and interpersonal relation skills, it has been realized that the skill levels of prospective teachers at the age of 19 for communication and interpersonal relations are higher than the prospective teachers who are at the age level of 18, 20 and 21. As a result for the overall scale, it has been found that the life skill levels of prospective teachers over 22 are higher than the prospective teachers who are at the age level of 18,20 and 21.

Between the prospective social studies teachers' class levels and the level of life skills, it has been seen that no significant difference is available in the factors of skills for coping with stress and emotions, empathy and self consciousness skills, creative and critical thinking skills, communication and interpersonal relation skills and in terms of the total score in scale-wide. A significant difference in the dimension of decision-making and problem solving skills factor has been found according to the class level variable. As based on the results obtained, it has been realized that the $4^{\text {th }}$-year prospective social studies teachers' decision-making and problem solving skill levels are higher than that of the prospective teachers receiving education at the $2^{\text {nd }}$-year level. This obtained result can be interpreted in the way that prospective teachers at the $4^{\text {th }}$-year level can make the decisions shaping their lives on their own and overcome the hitches and problems of life. Because the individual with life skills is an independent figure who can fulfill his own responsibilities, cope with the problems he encounters, make right choices for himself, has goals and makes an endeavor to achieve his goal (Kılıç, 2015).

It has been seen that no significant difference is available in the factors of skills for coping with stress and emotions, decision-making and problem solving skills, creative and critical thinking skills, communication and interpersonal relation skills and in terms of the total score in scale-wide, between the variable of a social institution, association and etc., which the PSSTs are member of and involve in their activities and the life skills sub-factor levels. But, a significant difference is seen in the dimension of empathy and self consciousness skills factor. According to these findings, it is seen that a result in favor of prospective social studies teachers being a member and involving in the activities of a social institution, association, and etc., is available for the levels of empathy and self consciousness skills. Self consciousness is a prerequisite for developing empathy with the others, as well as effective communication and interpersonal relationships, along with the individual's selfknowledge (Ulus, 2018). Also, life skills are an outcome of the combination of manual skills and psychosocial competences (UNESCO, 2004).

Between the variable of the university's academic club which the PSSTs join for relevant studies and the life skills sub-factor levels, no significant difference has been found in skills for coping with stress and emotions, empathy and self consciousness skills, and communication and interpersonal relation skills; however, it has been concluded that there is a significant difference in the factors of decision-making and problem solving skills, creative and critical thinking skills and in terms of the total score in scale-wide. In the light of the results obtained, it has been found that the prospective social studies teachers' decision-making and problem solving 
skills, creative and critical thinking skills are higher in the ones who take part in the relevant studies of an academic club than the others who don't join such academic clubs at university. In the research carried out by Kurtdede Fidan and Aydoğdu (2018), prospective classroom and science teachers expressed their opinions in the way that the activities performed in classes and other activities would be effective in teaching life skills.

While no significant difference has been found in the factor of skills for coping with stress and emotions, a significant difference has been seen in the factors of empathy and self consciousness skills, decision-making and problem solving skills, creative and critical thinking skills, communication and interpersonal relation skills and in terms of the total score in scale-wide, between the variable of the prospective social studies teachers' demand for receiving postgraduate education and the life skills levels. As based on the results obtained, it has been concluded that the empathy and self consciousness skill levels of prospective teachers who consider postgraduate education as improving oneself are higher than the others who do not want to receive postgraduate education. Also, the creative and critical thinking skill levels of prospective teachers who consider postgraduate education as improving oneself and ideal target have been found higher than the ones who do not want to receive postgraduate education. Furthermore, it has been realized that the decision-making and problem solving skill and communication and interpersonal relation skill levels of prospective teachers who have a desire for receiving postgraduate education by regarding it as improving oneself and also ideal target are higher, compared to the prospective teachers who do not want to receive postgraduate education. When the results for overall scale score are analyzed, it can be stated that the life skill levels of prospective teachers adopting postgraduate education as a way of improving oneself and an ideal target are higher than those of prospective teachers who do not want to receive postgraduate education. At this point, goal setting and/or targeting and career planning are of the most important life skills required to be supported for both individuals and society (Ulus, 2018).

\section{SUGGESTIONS}

In the light of research results, it is foreseen that the prospective social studies teachers' life skills will create a positive effect on their personal and social lives. In this regard, the following suggestions can be offered:

Pedagogical courses can be presented for the prospective teachers at faculties of education of universities for the improvement of their life skills. Thus, it can be ensured that prospective teachers have experience in transferring the life skills they acquire to their students.

The life skills that prospective teachers need may be determined and instructional programs for these determined skills may be prepared. In relation to the effectiveness of these programs, experimental researches and longitudinal studies may be performed. 


\section{REFERENCES}

Bolat, Y. \& Balaman, F. (2017). Yaşam becerileri ölçeği: geçerlik ve güvenirlik çalışması. Insan ve Toplum Bilimleri Araştırmaları Dergisi, 6 (4), 22-39.

Büyüköztürk, Ş., Kılıç-Çakmak, E., Akgün, Ö. E., Karadeniz, Ş., \& Demirel, F. (2011). Bilimsel araştırma yöntemleri. 10. Baskı. Ankara: Pegem Yayıncılık.

Compas, B. E. (1987). Coping with stress during childhood and adolescence. Psychological Bulletin, 101 (3), 393-403.

Karasar, N. (2010). Bilimsel araştırma yöntemi. 21. Baskı. Ankara: Nobel Yayınevi.

Kaur, J. \& Kaur Sandhu, K. (2016). Life skills as predictors of risk-taking behaviour among prospective teachers. Indian Journal of Positive Psychology, 7(2), 244-248.

Kaya, B. (2008). Sosyal bilgiler öğretmen adaylarının düşünme becerilerinin öğretimine yönelik öz-yeterliklerinin değerlendirilmesi. Yayımlanmamış doktora tezi, Gazi Üniversitesi, Eğitim Bilimleri Enstitüsü, Ankara.

Kılıç, Z. (2015). Hayat bilgisi dersinde öğrencilerin yaşam becerilerinin geliştirilmesinde etkin öğrenme uygulamaları. Yayımlanmamış doktora tezi, Anadolu Üniversitesi, Eğitim Bilimleri Enstitüsü, Eskişehir.

Koyuncu, B. (2018). The effect of pre-service teachers' life skills on teacher self-efficacy. Journal of Education and Learning, 7(5), 188-200.

Kurtdede-Fidan, N. \& Aydogdu, B. (2018). Life skills from the perspectives of classroom and science teachers. International Journal of Progressive Education, 14(1), 32-55, doi: 10.29329/ijpe.2018.129.4

MEB. (2018a). Sosyal bilgiler dersi öğretim programı (ilkokul ve ortaokul 4, 5, 6 ve 7. sınıflar). T. C. Milli Eğitim Bakanlığı, Ankara.

MEB. (2018b). Hayat bilgisi dersi öğretim programı (ilkokul 1, 2 ve 3. sınıflar). T. C. Milli Eğitim Bakanlığı, Ankara.

MEB. (2018c). Fen bilimleri dersi öğretim programı (ilkokul ve ortaokul 3, 4, 5, 6, 7 ve 8. sınıflar). T. C. Milli Eğitim Bakanlığı, Ankara.

Norman, M. N. \& Jordan, J. C. (2006). Targeting life skills in 4H. University of Florida, UF IFAS Extension.

Powell, M.F. (1995). A program for life-skills training through interdisciplinary group processes. Journal of Group Psychotherapy, Psychodrama and Sociometry, 38(1), 23-34.

Singh, H. \& Gera, M. (2015). Strategies for development of life skills and global competencies. International Journal of Scientific Research, 4 (6), 760-763.

Ulus, L. (2018). Ergen bireyler için yaşam becerileri. Avrasya Sosyal ve Ekonomi Araştırmaları Dergisi (ASEAD), 5 (12), 516-537.

UNESCO. (2004). Report of the inter-agency working group on life skills in EFA. Paris.

UNICEF (2012). Global evaluation of life skills education programmes. Final report,.United Nations Children's Fund, New York.

UNICEF, (2003, 13 Haziran). Definition of terms. Erişim adresi: https://www.unicef.org/lifeskills/index_7308.html 
Ümmet, D. \& Demirci, G. (2017). Yaşam becerileri eğitimi kapsamında yürütülen grupla psikolojik danışma uygulamasının ortaokul öğrencilerinin iyi oluşları üzerindeki etkisi. Marmara Üniversitesi Atatürk Eğitim Fakültesi Eğitim Bilimleri Dergisi, 45, 153-170, doi: 10.15285/maruaebd.263879

WHO (1997). Life skills education for children and adolescents in schools. Geneva: World Health Organization. 